\title{
Covid-19 a Gateway to Enhance China's Food Safety Culture
}

\section{Zhai Yuan $^{\mathbf{1}}$ and Watson Derek ${ }^{2 *}$}

${ }^{1}$ PhD Research Student, University of Sunderland, England, UK

${ }^{2}$ Associate Professor, University of Sunderland, England, UK

*Corresponding Author: Watson Derek, Associate Professor, University of

Sunderland, England, UK.
Received: December 04, 2020

Published: January 22, 2021

(C) All rights are reserved by Zhai Yuan and

Watson Derek.

DOI: 10.31080/ASMI.2020.04.0761

\begin{abstract}
Despite scientific advances, the continuous improvements associated with food safety management systems and increasing academic debate. There is a sobering reality in the twenty first century that 600 million people suffer from food contamination. China, through its 'One Belt One Road' Strategy is actively encouraging all enterprise sectors to export. However, the Chinese food sector has a tainted history of significant breaches in food safety compliance, which has significantly hindered its export market. The Covid-19 pandemic has once again turned global attending to China's food safety management systems with increased concern. This paper utilises the implementation of the Enlighten Food Safety Culture model to assess food safety culture within the Inner Mongolian Food Sector and to provides a food safe culture road to recovery in terms of safe practices and in turn strengthen China's food safety reputation.
\end{abstract}

Keywords: Covid-19; Culture; Enlighten Model; Food Safety; One Belt One Road

\section{Introduction}

The Covid-19 outbreak was traced in late 2019 to China, and was rapidly transmitted on a truly global scale with devastating economic effects and human costs. At present, in excess of 1.2 million people around the world have lost their lives to Covid-19 [1]. Although the exact source of the virus has not been scientifically confirmed, most studies have indicated that the virus originated from feral animals, and human beings were subsequently infected having consumed the food source [2,3]. Inconsequence, the level of food safety in China is once again under the lime light of global concern. China's customs have repeatedly detected Covid-19 virus in imported foods such as frozen pomfret and frozen prawns from Ecuador, the infected items were either returned or destroyed [4]. Improving the ability of managing food safety production is one of the best weapons for enterprises to avoid the recall and return of food safety problems which may damage the brand image and to strengthen supply line and consumer trust [5].

The "One Belt, One Road" initiative has been driven by Chinese government in recent years to encourage Chinese enterprises to export. However, there are serious food safety violations in China's food industry, which has caused a number of critical food safety incidents in recent years. In consequence this has strategically hindering the development of China's food export market and brand image. Thus the Covid-19 pandemic has again attracted the scrutiny and credibility in China's food safety management system. This study utilises the Enlighten Food Safety Culture model [6] to evaluate the food safety culture of Inner Mongolian Food sector and to identify a road to recovery to enhance China's food sector in meeting the 'One Belt One Road' global initiative.

\section{Background Literature Review}

Qijun and Batt [7] pointed out that China's food industry has developed significantly in terms of scale and sales since the economic "Reform and Opening Up" strategy launched in 1978. Furthermore, Kafetzopoulos and Gotzamani [8] stressed that since 2011, China's food industry has generated nearly 6.7 million jobs. This development has generated about 6.9 trillion CNY (about 1 trillion USD) of GDP growth, which is a distinct positive for China's food industry. In addition, Chen., et al. [5] believe that the continuous growth of national income has had a profound impact on the development of consumer consumption concept. Which has transitioned from high quantity and low price to healthy diet high quality foods, thus leading to the increasing demand for food safety [9]. 
Food safety can have a serious impact on people's health all over the world. A key consequence of the Covid-19 pandemic is that consumers are paying more attention to food safety [2]. According to the report of WHO [10], it is estimated that the health of about 600 million people in the world are directly threatened by food safety every year which result in 420,000 deaths a year. As mentioned, numerous food safety incidents have occurred in China in recent years. In 2012 alone, China reported 6685 food safety incidents, most of which were caused by microbial agents, toxic animals and plants, and chemical pollutants [11]. Although China has changed from a closely regulated country to a country gradually opening to the outside world, the hidden food safety incidents still exist. However, concealment is not unique to China and is common in many other countries. No country wants to be censored for reporting serious food safety incidents [9]. Wu and Chen [12] defined food safety as "ensuring that food will not cause harm to consumers when it is prepared and consumed as expected". Food safety is a global problem, affecting both industrialised and developing countries. According to Liu., et al. [11], it is estimated that up to $30 \%$ of the population living in industrialised countries suffer from foodborne diseases every year.

The effective management of food safety is crucial worldwide health, and this very much includes China, especially for metropolises like Beijing. As China has a large population, and its food supports its citizens and is a potential lucrative global market. This fact itself shows the importance in resolving China's food safety problems [12]. Wu and Chen [12] further point out that Beijing, the capital of China, is striving to become a global economic, political and cultural centre; therefore, any serious food safety incident will seriously damage the overall food brand of Beijing and China and has prompted the Government attentions to regulate and monitor food safety [9].

A key defence against contaminations in the food supply is food safety management system (FSMS), such as Hazard Analysis and Critical Control Point (HACCP). Furthermore, certified bodies such as the British Retail Consortium recognise the importance of food safety culture to ensure compliance and continuous improvement and now require its certified members to measure their food safety culture and devise a food safety culture plan which is auditable
[13]. However, Guo., et al. [14] emphasised the perceived restrictions and obstacles of using third-party resources to implement the food supervision system in China. A fundamental hinderance is that many Chines businesses do not see a cost benefit in the investment and adoption of third-party food safety certification. The irony is that food safety certification is a precursor to export to the global market [15]. However, Xiong., et al. [16] highlighted that the size of enterprises has a significant impact on the implementation of third-party food supervision or food management system. For a country like China, the enterprise scale is the most important aspect of whether to carry out the third-party food safety certification.

Tian [17] introduced the application of HACCP system, which defined $38 \%$ of the implementation process, and provided positive results for the food regulatory system of China's food industry. On the other hand, Tse., et al. [18] believes that the $19 \%$ failure rate determines that the use of third-party certification is inappropriate, and the Chinese food industry has not observed the expected results. According to Patrick., et al. [19], the failure of FSMS is usually attributed to emerging food risks, customs rejection due to safety non-compliance, emerging processing technologies, marketing and distribution, and other complex factors. However, studies have also shown that the root cause is often attributable to non-compliance and management's failure to effectively manage its employees [20]. Kupper and Batt [21] believe that the lack of training and reliable supervision from management will weaken the effectiveness of FSMS. The use of effective leadership and management in the quality control of food production can be classified as one of the most important internal barriers and constraints in adopting the spirit or culture of FSMS. Motarjemi and Kaferstein [22] further support the view that appropriate quality management control of FSMS is more important than FSMS itself for safety production. Nyarugwe., et al. [23] pointed out that the existing measures to ensure safe food production are not perfect due to repeated food borne outbreaks. They further pointed out that the senior management of food companies repeatedly fail to appreciate that employee behaviour is not static, but an ever-changing multidimensional criterion, which requires their full and continuous attention in terms of time, resources and commitment. This involves the cultural management of enterprises. 
Griffith., et al. [24] found that although the concept of factory or corporate culture affects employee behaviour, it has been largely ignored in the food processing industry. However, many industries around the world are increasingly interested in safety culture as a means to prevent and reduce safety accidents [25]. In consequence, both academics and industrial practitioners are stress the need for more research on food safety culture. As the concept is not well understood at all levels in the food industry, including middle and senior managers [24].

Corporate culture is essentially created by management and through the vehicle of management models, it can reach and connect with employees (i.e. first-line labour) in terms of food safety culture compliance [6]. However, in the public perception, the term culture is also difficult to quantify and grasp. Furthermore, Jespersen., et al. [25] found, the concept of food safety culture has not been fully understood throughout the food industry. De Boeck., et al. [26] believe that there is no effective tool or model to accurately measure the relationship between food safety culture and enterprise benefits. However, Watson., et al. [6] combined with the best practices of several food processing enterprises and well-known food consulting companies in the UK, creatively proposed the Enlighten Food Safety Culture Model (EFSCM), which divided food safety culture into four interconnected parts, namely, control, cooperation, communication and competence, so as to achieve the goal of classifying and quantifying food safety culture and then implementing a road to recovery and enhancement.

The use of The Enlighten Food Safety Culture Model makes it possible to quantify the food safety culture of enterprises, so as to meet the requirements of the latest version of British Retail Consortium Global Standard (BRCGS) and additional third-party food safety management certification on enterprises to reflect their own food safety culture performance.

\section{Method}

Utilising the Enlighten Food Safety Culture Model, a qualitative approach was selected. The raw data were retrieved from two large and six medium-sized food producers and the Inner Mongolia Food Federation through 30 semi-structured interviews and two focus groups (each group consisted of 7 participants) The researchers thematically analysed the data and linked the core themes within the four 'C's' of the Enlighten model, namely control, cooperation, communication and competence.

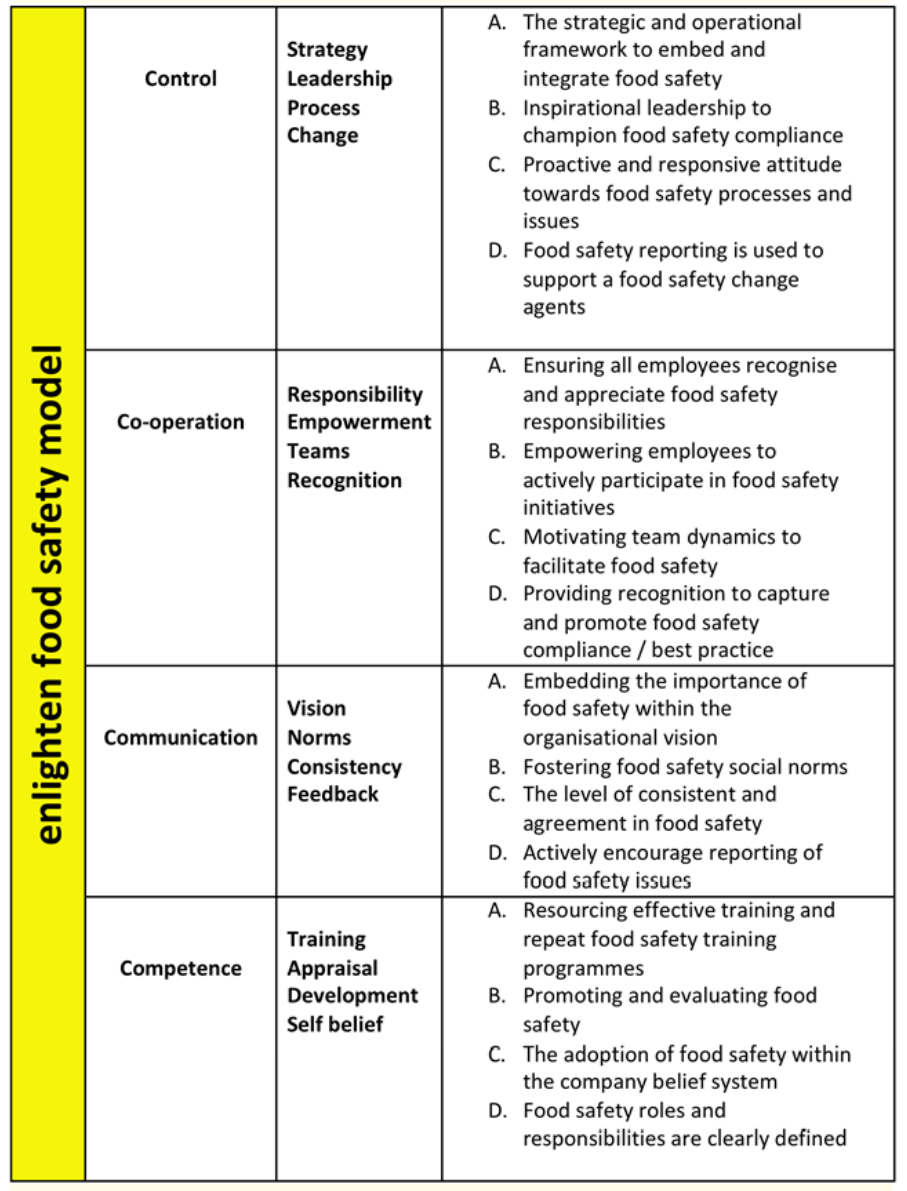

Figure 1: The Enlighten Food Safety Culture Model [6].

The purpose of this study is to explore the importance and understanding of food safety culture in China's food processing enterprises. According to the research results of Tse., et al. [18], there are many irregularities in the implementation of the third-party food safety management system by Chinese food producers, and it is difficult to realise the cost-effectiveness when implementing the internationally recognised food safety management system. The use of "Enlighten Food Safety Culture Model" is aimed to help to explore the key barriers to effectively embedding and cultivating a food safety culture system in food production enterprises in terms of control, cooperation, communication and competence. Without resolve, such organisations are struggling to dispel China's compliance to food safety and will continue to hinder China's positive food safety cultures and China's 'One Belt One Road' initiative on exporting strategy of food, on a truly global scale. 


\section{Results}

Control

Through the interview survey, the researchers found that in the small and medium-sized food enterprises, in terms of safety control, enterprises tend to reflect passive management and in which employees are forced to comply with food safety regulations via mandatory means, such as 24 -hour closed-circuit television monitoring and other technical techniques. Mandatory means can play an important role in the process of food safety traceability, and can implement the food safety responsibility to a certain member of staff. However, it may not play a positive role in the prevention of food safety incidents. As Griffith., et al. [24] found that the concept of factory or corporate culture that effects employee behaviour has been largely dismissed in food processing industry. The food safety culture of the enterprise's had not been mentioned by the interviewees, suggesting that food safety has not been incorporated into their corporate strategy. Due to the rapid turnover of new and old employees, which is due to China's urbanisation movement and poverty alleviation, resulting in a large number of rural labour force entering the city to work in order to rise their income. However, such a labour force generally has a low level of education. In addition, enterprises pursue efficient operations, and the safety training time for employees is generally short, so it is uncertain whether the employees can be completely master the standardised operation's in a short period of time. From this point of view, for small and medium-sized food enterprises, when the food safety culture has not penetrated into the heart of every employee, passive food safety management has become the mainstream. This conclusion confirms the findings of Guo., et al. [14] studies of obstacles in the implementation of the third-party food safety management system, including inadequate training for employees, resulting in employees' poor understanding of food safety compliance, thus increasing the chances of food safety incidents caused by human factors. At the same time, it will prove problematic when international food safety certification is required to meet the export requirements, as Kupper and Batt [21] believe that the lack of training and reliable supervision from management will weaken the effectiveness of FSMS.

The representative speeches of the interviewees are listed below:
- $\quad$ Respondent A: "The food safety production control of our chain restaurants is mainly reflected in the following two aspects: 1 . We select raw material suppliers with complete certification, such as pork suppliers must have inspection and quarantine certificates issued by the government, and vegetable suppliers must provide pesticide residue testing certificates. We will reserve samples for each batch of raw materials for traceability after possible food safety incidents. 2. Closed circuit televisions are used in the kitchen and dining area of our restaurant to realise real-time monitoring without dead corners, which can completely record a dish from the processing of raw materials to the end of the guests' eating. When the guests report that the dishes cannot reach the expected sanitary conditions, we can trace the hygiene problems of the dishes throughout the whole process, so as to accurately implement the responsibility to each employee".

- $\quad$ Respondent B: "We are in the food roughing industry, such as peeling and vacuum packaging corn and then supplying it to wholesalers. We sign purchase contracts with farmers to provide them with seeds and planting techniques. Our technicians regularly help farmers apply chemical fertilisers and pesticides to prevent diseases and insect pests. The dosage of chemical fertilisers and pesticides is recorded every time. When the crops are mature and collected, we will carry out pesticide residue detection, and only qualified crops can be put into storage. After vacuum packaging, we will carry out sampling inspection on each batch of products to ensure the quality and safety of products".

- $\quad$ Respondent C: "To ensure food safety has always been the top priority of our food enterprises. We have a complete set of complete operation specifications. All employees must undergo at least three days of pre job training before taking up their posts, so that they are fully familiar with the standardised operation. We have introduced HACCP and ISO series quality management systems to ensure that food safety is effectively protected in the whole production process, and the production line strictly implements the pharmaceutical level sanitary disinfection standard. Closed circuit televisions are installed in the plant area, and there is no dead corner for 24 hours, and the supervision is carried out continuously by special personnel". 


\section{Co-operation}

The interviews indicated that the cooperation among employees in small and medium-sized enterprises is generally poor, especially among the management system. There is hardly any mutual cooperation between the management team, because the decisions are usually decided by the owner. The middle-level management and operational employees can only complete the work according to the requirements of the leaders. This finding supports the work of Jin., et al. [20], who have shown that the root cause usually associated with non-compliance is management's failure to effectively manage its employees.

Internal management mechanism without cooperation is invariably unsuccessful. In fact, such a management culture belongs to the category of traditional Chinese management philosophy, namely, Confucianism. In which, Chinese people have been educated from childhood to respect teachers, education and elders. Therefore, they have been accustomed to obey the instructions of their elders or teachers since they were young, so that when they enter into the work market, they habitually obey the instructions of the leaders without question.

Without the mutual communication between the management, it is difficult for the business owner to consider comprehensively the consequences and thus leading to mistakes and repeating the same mistake. Xiong., et al. [16] explained that the size of enterprises has a significant impact on the implementation of third-party food supervision or food management system. From this point of view, the results have shown that China's small and medium-sized food enterprises do not have the ability, nor motivation, to fully implement the third-party food safety management model. The survey results indicated that large companies do relatively well in the implementation of management mode, and can invariably achieve cooperation due to more robust training and investment. Watson., et al. [6] also found that corporate culture is essentially created by management the minority and effects the majority i.e. the workforce. Management action and inaction will directly or indirectly influence the culture. Rather like a thermostat, management have the power to turn up or down the safety cultural compliance. It can be concluded that China's large enterprises still have potential in the implementation of third-party food safety management system, in comparison to small and medium-sized enterprises in the management system optimisation.

The representative speeches of the interviewees are listed below:

- Respondent D: "In China's small enterprises, a common phenomenon is that the owner manages everything and the employees get it; the boss is fully responsible for everything, and the subordinates only implement the top manager's orders; the owner needs to handle all the major and minor matters in person, and the subordinates can only cooperate with the work. The same is true of middle-level management in small enterprises, no matter big or small matters need to be decided by the owner himself. So sometimes even if there is a good idea, the idea cannot be implemented as long as the boss does not give timely affirmation. Maybe a leader is still capable for everything if there are only ten or twenty people in a small enterprise. Once the enterprise experiences rapid development, without the management team that can unite and cooperate, the enterprise cannot run smoothly".

- Respondent E: "As the person in charge of the enterprise, I will pass the task to the middle-level managers, allocate the resources and delegate the power. Let the middle-level managers to perform their duties, there is the concept of cooperation in this small management circle. Let them do what they can to influence their employees. Encourage them to work together to solve problems rather than arbitrate everything my selves. Give guidance to the subordinates who don't use their brains to report everything. I always ask my middle-level managers the following questions: what measures have you taken, who have you listened to, and what steps have you taken to solve a problem? Do you really want me to help you with this?"

- $\quad$ Respondent F: "Employees of small and medium-sized enterprises generally regard work as a means of making a living. They have no lofty aspirations and have no extravagant expectations for money. In addition, their learning ability is not strong, and half of them hold the idea of muddling 
along. Therefore, we should make careful preparation for their training. According to their psychological acceptance ability and personality characteristics, we should make targeted preparation for training programs, arrange more case explanations and less mention of theories; let them participate more, and make less mystery; more laughter and less serious".

The results from the interviews suggest that the personnel generally believe that there is a lack of communication between employees or between management and front-line employees in domestic enterprises. Interviewee ' $G$ ' mentioned that "Chinese people have always regarded "less talking, more doing as a treasure, and that silence is the gold". They firmly believe that hard work is the magic weapon to be brilliant". Motarjemi and Kaferstein [22] concluded, that appropriate quality management control of FSMS is more important than FSMS itself for safety production. Thus, the communication problems actually represent the failure of management. If front-line employees master the first-hand information of food safety production and cannot effectively inform the management. Then the food safety production risk will be increased because of the fact that information communication is not timely in the implementation of the food safety management system. Guo., et al. [14] pointed out, the specific performance is that the recognition of enterprises for third party food safety certification is not high on the agenda, if at all, as the enterprise management team often fail to recognise what benefits food safety management system certification can bring to enterprises.

Whether referring to specific third-party food safety standard such as BRCGS Issue 8 [13] or HACCP, communication and cooperation between the upper and lower levels are emphasized. The interview results also indicated that the management failed to consult the staff, and in the justification or rational of organisational changes. Some employees also said that they didn't care what kind of changes the company made to food safety standards or standardised operations, but only in how long they needed to work and how much money they could get. There was however evidence that some companies establishing an internal mailbox so that employees can voice their ideas. However, without the promotion of the initiative by management and a culture of silence, such systems are redundant.

The representative speeches of the interviewees are listed below:

- Respondent G: "The Chinese have always regarded "less talking, more doing" and "silence is the gold" as a treasure, insisting that hard work is the magic weapon for the cause to be brilliant. But ignore a person in the team, good communication is a necessary ability. As a team, the communication ability among members is the necessary condition to maintain effective communication and vitality of the team".

- Respondent H: "I feel like I'm just working for the company, but I'm not a part of it. The management did not consult us, did not ask our opinions, did not explain what happened or the reasons for the change, but they reorganised everyone's work. We are not treated as part of the company at all, which is a big morale blow and a big drop in everyone's productivity. Take me as an example, I used to work very hard, often working overtime and paying a lot of effort for my work. But now, we are completely out of control of our work, so that the hope of doing a good job is dashed, and the success of the work is no longer my problem".

- Respondent I: “I think our company's communication from the superior to the subordinate is smooth. The policies I want to implement can be well implemented by the subordinates. However, it is very difficult for me to hear the opinions of the subordinates on the policies proposed by me. This may be related to our traditional culture and education. In schools, we were taught to strictly obey the instructions of teachers, and strictly obey the instructions of superiors after entering the company. I have also tried to break this inherent concept, so that employees can truly reflect their ideas. For example, a mailbox has been set up in the company, and employees can put their opinions into the mailbox, and then I will review them. However, the situation is not ideal. Employees basically hide their real ideas".

Citation: Zhai Yuan and Watson Derek. “Covid-19 a Gateway to Enhance China's Food Safety Culture”. Acta Scientific Microbiology 4.2 (2021): $19-28$. 


\section{Competence}

The interviewed enterprises indicated that the ability of employees is mainly improved through targeted training and examination. However, it is still questionable by the researcher's as to whether the training of employees is sufficient and question if they can fully understand the knowledge required in standardised production. As noted China's labour force generally has a low level of education, coupled with the pursuit of efficient operation, and the safety training time for employees is minimal. Interviewee ' $\mathrm{C}$ ' said that "we would provide at least three days of training for new employees to fully understand the standardised production". Using general knowledge as a loose benchmark of measurement to believe that a three-day training period will transform a low-level front-line employee to a level of competency to the content of standardised production is questionable. Recall Kupper and Batt [21] concluded that the lack of training and reliable supervision from management will weaken the effectiveness of FSMS. Therefore, employees' understanding of food safety compliance directly determines the risk level of food safety incidents. According to the research of Watson., et al. [6], the key to implement the third-party food safety management system is through the competence of its employees, which is why the company should emphasise the importance of food safety culture in enterprises.

Enterprises strive to improve the management predominantly through job rotation, to enable management a developmental process to grasp the importance and responsibilities of different departments and different positions. This arrangement sounds good, but combined with the analysis and discussion in the previous cooperation and communication sections, there is little evidence of an effective communication mechanism between the management and the employees. The separation of the front-line staff and the management in training schedules will undoubtedly aggravate the communication gap. As shown by Watson., et al. [6], the food safety culture of an enterprise is related to every employee of an enterprise. Effective cooperation and communication are key factors in determining whether an enterprise can effectively implement and manage the third-party food safety certification.
The representative speeches of the interviewees are listed below:

- $\quad$ Respondent J: "The first is to strengthen the annual training of middle-level managers of enterprises through demand research, setting up special forums by specialty, and sending personnel for training; the second is to organise cadres' job rotation and exchange in an orderly way through cross department, cross specialty and cross sequence rotation, so as to further expand the business field and comprehensively improve the comprehensive management ability of cadres; the third is to improve the selection and training of reserve cadres Training system to speed up the professional upgrading and comprehensive quality training of the company's backbone talents. We also regularly organise and carry out the general examination and adjustment of personnel of all professions and levels, and organise annual skills competition in a planned way. Through the competition to find the gap, find the problem, adjust the training plan and training content in time".

- $\quad$ Respondent K: "We establish the sense of responsibility that the quality of employees should be cultivated by different levels of organizations, make clear that training is the responsibility requirement of the top leaders of units at all levels, further clarify the training responsibilities of human resources department, training centre and all units, and fully mobilize the initiative and enthusiasm of units at all levels to participate in the training. To form a hierarchical training mechanism with the human resources department as the main function, the training centre as the implementation organisation, and the employing units as the cooperative departments. Strengthen the management of employee training satisfaction evaluation, and the follow-up evaluation of training results application. Through the way of random sampling questionnaire, timely collect the response evaluation of training courses, training organisation and teachers' teaching; carry out the effect evaluation of corresponding knowledge and skills training in a timely manner by means 
of theoretical examination and skill assessment; regularly visit trainees and employing departments to analyse the promotion effect of staff training on work performance before and after training, and carry out the evaluation of training results".

- Respondent L: "There are many problems in the process of training according to the plan. In this process, it is a process of finding and solving problems, so that new employees can learn lessons, recognize mistakes and correct mistakes. In many cases, new employees must be allowed to do it by themselves. Only when the trainer is an embodiment of his identity as a coach, what kind of leadership can he bring out What kind of employees, training new employees must be strict requirements, in this process, there must be rewards and penalties, in order to quickly improve the enthusiasm of new employees, but also let them see their own progress. In this process, we should not let new employees feel conceited when they feel that they are excellent students, nor should they be too harsh to let them have no confidence. These are two extremes, which should not be tolerated. Make sure that new employees operate within the framework you set, that is, you can't rush for success or indulge too much. You should stimulate the interest of new employees from time to time to improve their enthusiasm".

\section{Conclusion}

This study discussed the four 'Cs" of the Enlighten Food Safety Culture Model [6], namely control, cooperation, communication and competence. After the central government launched the 'One Belt One Road' strategy, especially in the context of the outbreak of Covid-19, and that the world consumers are more concerned about food safety issues. Researcher's endeavoured to explore whether China's food enterprises have export capacity and the effect of the implementation of the third-party food safety international certification in domestic food enterprises.

The survey results showed that the most prominent problem in the management of small and medium-sized enterprises in China lies in the cooperation and communication between employees and managers or between management team and top leaders. Poor cooperation and communication between employees and managers and between management team and enterprise owners has become a common problem in small and medium-sized enterprises.
It is attributable the Chinese cultural norm in obeying orders, being silent, and a conditioning in not expressing their own opinions. Another major problem lies in the fact that enterprises endeavour to reduce the duration training in pursuit of commercial interests, which results in employees' failing to grasp a competent understanding of food safety rules and regulations, and increases the possibility of non-compliance in food production.

Thus, the reality is that there is still a high risk of non-compliance in China's food enterprises, especially in small and mediumsized enterprises, to implement the third-party international food safety certification such as BRCGS or HACCP. It can be concluded that the current management mode of China's small and mediumsized enterprises cannot eliminate the risk of food safety non-compliance caused by human factors as a consequence of poor unattended safety cultures. In consequence, too naively push ahead in the exporting of food products without the prerequisite of securing an international food quality certification and failing to address the issues identified around control, co-operation, communication and competence will only further taint China's food safety assurances and be met with resistance from international supply chains.

\section{Appendix 1}

\begin{tabular}{|c|c|c|c|c|}
\hline $\begin{array}{c}\text { Responder's } \\
\text { code }\end{array}$ & $\begin{array}{c}\text { Industry } \\
\text { type }\end{array}$ & Job title & $\begin{array}{c}\text { Years of } \\
\text { current } \\
\text { employed }\end{array}$ & $\begin{array}{c}\text { Years of } \\
\text { working } \\
\text { in food } \\
\text { industry }\end{array}$ \\
\hline A & $\begin{array}{c}\text { Chain } \\
\text { restaurant }\end{array}$ & Owner & 15 & 20 \\
\hline B & $\begin{array}{c}\text { Food } \\
\text { roughing }\end{array}$ & Owner & 10 & 26 \\
\hline C & $\begin{array}{c}\text { Dairy } \\
\text { QC Manager }\end{array}$ & 6 & 10 \\
\hline D & $\begin{array}{c}\text { Food } \\
\text { federation }\end{array}$ & President & 5 & 10 \\
\hline E & Dairy & Owner & 10 & 25 \\
\hline F & $\begin{array}{c}\text { Food } \\
\text { federation }\end{array}$ & $\begin{array}{c}\text { Chief } \\
\text { Secretary }\end{array}$ & 5 & 5 \\
\hline G & $\begin{array}{c}\text { Food } \\
\text { federation }\end{array}$ & $\begin{array}{c}\text { Marketing } \\
\text { Manager }\end{array}$ & 3 & 6 \\
\hline H & $\begin{array}{c}\text { Dairy } \\
\text { Production } \\
\text { line staff }\end{array}$ & 3 & 5 \\
\hline I & Dairy & Owner & 6 & 15 \\
\hline J & Dairy & HR Manager & 7 & 8 \\
\hline K & $\begin{array}{c}\text { Food } \\
\text { federation }\end{array}$ & $\begin{array}{c}\text { Vice } \\
\text { president }\end{array}$ & 5 & 25 \\
\hline L & $\begin{array}{c}\text { Food } \\
\text { federation }\end{array}$ & HR Manager & 4 & 20 \\
\hline & & & \\
\hline
\end{tabular}

Table 1: Information of interview responders. 


\section{Bibliography}

1. WHO. COVID-19 Weekly Epidemiological Update (2020).

2. Zuber S and Brüssow H. "COVID 19: challenges for virologists in the food industry". Microbial Biotechnology 13.6 (2020): 1689-1701.

3. Lam TT., et al. "Identifying SARS-CoV-2 related coronaviruses in Malayan pangolins". Nature 583 (2020): 282-285.

4. Xinhua Net. The General Administration of Customs implemented emergency preventive measures against imported cold chain food producers with new coronavirus detected (2020).

5. Chen E., et al. "Implementation of non-regulatory food safety management schemes in New Zealand: A survey of the food and beverage industry". Food Control 47 (2015): 569-576.

6. Watson D., et al. "Brexit and the Implications of Food Safety Cultural Compliance in the Food Manufacturing Sector". Journal of ACTA Scientific Microbiology 1.4 (2018): 54-62.

7. Qijun J and Batt PJ. "Barriers and benefits to the adoption of a third-party certified food safety management system in the food processing sector in Shanghai, China". Food Control 62 (2016): 89-96.

8. Kafetzopoulos DP and Gotzamani KD. "Critical factors, food quality management and organisational performance". Food Control 40 (2014): 1-11.

9. Yang L., et al. "A systematic review of China's food safety management since reform and opening up". Emerging Markets Finance and Trade 55.15 (2019): 3472-3489.

10. WHO. WHO estimates of the global burden of foodborne diseases (2015).

11. Liu Y., et al. "Insights into the nature of food safety issues in Beijing through content analysis of an Internet database of food safety incidents in China". Food Control 51 (2015): 206211.
12. Wu Y and Chen Y. "Food safety in China”. Journal of Epidemiology and Community Health 67.6 (2016): 478-479.

13. BRC. British Retail Consortium Global Standard 8 Food Safety (2018).

14. Guo Z., et al. "Government regulations and voluntary certifications in food safety in China: A review". Trends in Food Science and Technology 90 (2015): 160-165.

15. Rincon-Ballesteros L., et al. "Implementation of the BRC food safety management system in Latin American countries: Motivations and barriers". Food Control 106 (2019): 1-9.

16. Xiong, C., et al. "Performance assessment of food safety management system in the pork slaughter plants of China". Food Control 71 (2017): 264-272.

17. Tian F. "An agri-food supply chain traceability system for China based on RFID and blockchain technology". IEEE 13th International Conference on Service Systems and Service Management (ICSSSM) (2016): 1-6.

18. Tse D., et al. "Blockchain application in food supply information security". IEEE International Conference on Industrial Engineering and Engineering Management (IEEM) (2017): 13571361.

19. Patrick Murigu Kamau Njage., et al. "Scale of production and implementation of food safety programs". Food Control 85 (2018): 85-97.

20. Jin S., et al. "Adoption of HACCP system in the Chinese food industry: A comparative analysis". Food Control 19 (2008): 823-828.

21. Kupper G and Batt PJ. "Barriers to the adoption of quality assurance systems in the food and beverage sector". Stewart Postharvest Review 5.3 (2009): 1-5.

22. Motarjemi Y and Kaferstein F. "Food safety, hazard analysis and critical control point and the increase in foodborne diseases: A paradox?" Food Control 10 (1999): 325-333. 
23. Nyarugwe SP., et al. "Determinants for conducting food safety culture research". Journal of Trends in Food Safety Science and Technology 56 (2016): 77-87.

24. Griffith CJ., et al. "The assessment of food safety culture". British Food Journal 112.4 (2010): 439-456.

25. Jespersen L., et al. "Development and validation of a scale to capture social desirability in food safety culture". Journal of Food Control 82 (2017): 42-47.

26. De Boeck E., et al. "Food safety climate in food processing organisations: development and validation of a self-assessment tool". Journal Trends in Food Science and Technology 46 (2015):

242-251.

\section{Assets from publication with us}

- Prompt Acknowledgement after receiving the article

- Thorough Double blinded peer review

- Rapid Publication

- Issue of Publication Certificate

- High visibility of your Published work

Website: www.actascientific.com/

Submit Article: www.actascientific.com/submission.php

Email us: editor@actascientific.com

Contact us: +919182824667 